\title{
THE LITHUANIAN REAL ESTATE TAXATION SYSTEM IN THE CONTEXT OF ALIEN COUNTRIES
}

\author{
Vida MALIENĖ ${ }^{1}$, Daiva CIBULSKIENE் ${ }^{1}$ and Virginija GURSKIENE் ${ }^{2}$ \\ 1 Department of Construction Economics and Property Management, Vilnius Gediminas Technical University, \\ Sauletekio al. 11, LT-10223 Vilnius-40, Lithuania \\ E-mail:Vida.Maliene@st.vtu.lt; daiva@boo.lt \\ 2 Department of Land Management, Lithuanian University of Agriculture, Studentug. 11, LT-53361 Akademija- \\ Kauno r., Lithuania \\ E-mail: zt@nora.lzuu.lt
}

Received 14 June 2004; accepted 10 January 2005

\begin{abstract}
The article aims at investigating the Lithuanian real estate taxation system in the context of the taxation system of the United States of America and European countries. The article dwells on the current situation in Lithuania; it introduces the advantages and drawbacks of the system and produces a comparative analysis as against alien countries. Proposals for the refinement of the Lithuanian real estate taxation system are presented on the grounds of the analysis results and alien experience. The article considers real estate tax base, analyses currently actualized tax reforms, and describes the impact of the changes on the real estate market. A number of principal features of real estate tax system commonly intrinsic to all considered countries, such as form of payment, basis of valuation, tax exemption, appeals, tax deductions, are discussed in the article.
\end{abstract}

KEYWORDS: Property tax; Basis of valuation; Taxpayer; Exemptions; Appeals

\section{INTRODUCTION}

The property tax is an important source of government revenues in many parts of the world. Property taxes tend to be levied at the local level, thus there are a great deal of bodies using this tax. They have many diverse needs and often have limited capabilities to understand and make use of the tax. As Lithuania currently is on the way of imposing the property tax, it is extremely important to learn by the experience of foreign countries in order to adopt strongest sides of property taxation policies and avoid eventual mistakes.

This comparative survey provides a basis for identifying a number of emerging political and economic issues of importance for the future debate on the structure and function of the property tax. The most significant current is- sues arising from the property tax may be broadly grouped into three categories: firstly and most generally, the function of a real property tax within tax systems largely depend on income or value-added taxes; secondly, the appropriate base for the imposition of such a tax; and finally, the role of an autonomous revenue source for the local government - an issue closely related to questions concerning the appropriative role of the local government itself. This practice in one or other way is used in the property taxation issues of alien countries [2]. Therefore, as far as it concerns the nature of the property tax, Lithuania can learn by the experience in many fields: the distribution of its ultimate economic burden, its impact on real estate prices, and its contribution to political values as the accountability of public officials and the visibility of revenue raising devices. 
A better understanding of political issues pertaining to the property tax, including its visibility, acceptability, and the role of supporting the local government, is equally critical in terms of efforts to improve its operation in Lithuania. Although these questions are necessary closely related to the political structure of a specific country and its current developments, attention to such individual cases can give insights that will assist in analyzing and corresponding with situations elsewhere.

\section{PROPERTY TAX SYSTEM IN THE UNITED STATES OF AMERICA}

The property tax is the only and most important source of the tax revenue for most local governments in the United States, and it has been an outstanding issue of the tax system since the time of the colonial government. The taxation of real property is governed by the constitutions and laws enacted by each of the fifty states and the District of Columbia.

Although the state governments establish the legal framework for the state and local taxes, they generally have a limited role in the actual administration of the property tax. Most state governments introduce standards and procedures, monitor quality and uniformity, and provide training and assistance to local assessing units, yet local governing bodies are primarily responsible for valuation, assessment and collection. In most states, the property tax is administered independently of other administrative offices.

The basic principles of property valuation and administration are well established in the United States. In the last fifteen years significant progress has been made in increasing the professionalism of assessing personnel through education and certification programs, in developing techniques for mass appraisal, and in making use of computers for greater accuracy and efficiency. The federal government neither taxes real property nor participates in its administration, but its constitutional provisions, especially guarantees of equal protection by the law and due procedure, apply to all forms of government action. Through legislation known as the $4 \mathrm{R}$ Act the federal government directly addressed administration of the property tax to counteract over-assessment of property by individual states in interstate commerce $[5,8,9]$.

\subsection{Tax Base, Rate and Exemptions}

All bodies tax the capital value of land and improvements, but the tax base and the levels of assessment and taxation differ from state to state (see Table 1). Generally state laws require property to be assessed on the basis of a fair market value. The state of California is unique in assessing property at its full market value only when sold; otherwise, taxes are based on values assessed in 1976 with a two percent maximum annual increase.

All but seven states require all assessing units to maintain the same assessment level and the definition of the value. A few merely require that values should be uniform and equitable within the assessing unit. Sixteen states and the District of Columbia require property to be assessed at 100 percent of the market value. Twenty-six states specify statutory percentages based on the market value; of these, thirteen states provide for different levels of assessment in various property classifications. Residential property is the primary recipient of preferential treatment.

Table 1. Annual Land and Property taxes - the United States of America

\begin{tabular}{|c|c|c|c|c|c|c|c|c|c|c|c|}
\hline \multirow[t]{2}{*}{ Tax } & \multicolumn{3}{|c|}{ Taxable Item } & \multicolumn{3}{|c|}{ Taxpayer } & \multicolumn{4}{|c|}{ Basis of Valuation } & \multirow[t]{2}{*}{ Revaluations } \\
\hline & Land & Building & Plant & Owner & Occ & Both & Rental & Capital & Area & Other & \\
\hline $\begin{array}{l}\text { Local } \\
\text { property } \\
\text { tax }\end{array}$ & $\checkmark$ & $\checkmark$ & & $\checkmark$ & & & & $\checkmark$ & & & $\begin{array}{l}\text { Depends on } \\
\text { state } \\
1-5 \text { years }\end{array}$ \\
\hline
\end{tabular}


Tax rates are determined as the part of the annual budget circulation by nearly 83,000 local government units in the fifty states, including counties, municipalities and townships, and special taxing districts for schools and other services. Thirty-five states tax all categories of property at the same rate; sixteen states and the District of Columbia apply different tax rates according to a property class.

Property tax exemptions are constitutionally or statutorily mandated by the state law, but some states permit local discretion in application of certain exemptions. All states exempt government-owned property from property taxation. Property in religious and educational use is generally exempt from taxation, although the definition and extent of the content may vary. Charitable institutions are largely exempt from property taxes in the United States, but state laws differ in terms of the qualifications for charitable exemption. Other common exemptions include hospitals and cemeteries. A few states provide exemptions for historical heritage, forests and orchards, mines, and transportation property [9].

\subsection{Intergovernmental Organization and Sources of Information}

Each state's constitution and statutes establish the legal basis and organizational structure for property assessment and taxation. State responsibility for property tax administration is most often vested in a division of the state's Department of Revenue Taxation (29 states) or the State Tax Commission (8 states). The independent state Board of Equalization is responsible for assessment administration in four states, including California, New York, Pennsylvania and Tennessee. Maryland's Department of Assessments is an independent agency with responsibility for all assessing functions.

The primary assessing units in each state collect and manage information requisite for valuation of property located within their jurisdiction. Legal descriptions of property and property ownership are usually recorded in a county court or registry of deeds in the county court where the real estate is located. Most but not all states require transfers of ownership and sales prices to be recorded.

Cadastral assessment or tax maps are produced and maintained by the assessor, and are generally a complete and accurate graphic inventory of all parcels. Arial base maps may be provided by the state or procured by the local government for the assessor's use. Now paper maps are increasingly being replaced with digital computerized mapping [9].

\subsection{Valuation, Tax collection and Appeal procedures}

The basic principle underlying the valuation of property for tax purposes in the United States is that property is to be appraised at its market value according to its highest and best economic use. Most states, however, prescribe by the law that certain categories of property are to be valued according to the "current-use". In determination of the market value, assessors use the three traditional approaches to value: comparable sales, replacement cost less depreciation and income capitalization.

While nearly all states provide for the annual assessment and taxation of property as of a specific assessment date, most commonly $1^{\text {st }}$ January or $1^{\text {st }}$ July, only 31 states require by the law a periodic reappraisal of all property for assessment purposes. The specific time intervals between reappraisals vary from one year to ten, with 73 percent having one- to fiveyear cycles. Individual parcels are revalued annually if there have been changes made to the property due to new construction, demolition, damage, etc.

With the decrease of the cost and size of computers, computerization of assessment functions has steadily increased. The extent of computer use varies considerably among the states and among the assessing units within the states. Automation prevails in the localities where the 
state agencies provide computer services or assistance.

Assessment of property and collection of property taxes are independent government functions. Tax collection is incumbent on public officials, whose duties are prescribed by the state law as well as by the local ordinance. Taxes imposed by various special districts, such as school, water or fire districts, may be consolidated by a county or municipal tax collector to be issued in a single bill or may be levied independently by each taxing entity. Property taxes are collected on an annual cycle in all states, with most (27) allowing two installments. One payment is required in thirteen states, and the remainder permits three or four payments. Deadlines for initiating an appeal vary among states, and are established by the state law. There is normally a minimum of two weeks notice, with a common period of thirty days between the mailing of the notice and the deadline for submitting the complaint. Assessment or tax notices must include information on the taxpayer's appeal rights and the deadline for filing of formal appeals. In the states where the process is initiated after tax billing, the filing of an appeal does not defer the payment of the tax.

Taxpayers are generally aware of and exercise their appeal rights. The frequency of appeals varies among assessing units and from year to year based on numerous economic, governmental and political factors. On the average, less than 10 percent of property owners appeal [9].

\section{PROPERTY TAX SYSTEM IN EUROPE}

The impact of taxation is becoming a more important factor in deciding where to locate a business than ever. Only recently the Dutch Ministry of Finance expressed particular concern over the differences in taxation regimes and rates across Europe and the effects that this was having on their economy.

Good knowledge of property taxation in Europe is useful not only for accountants and property professionals but also to businesspersons who need advice as to what taxation liability they will incur if they rent or buy property in another European country. Normal tax regimes of most countries are more than well documented, yet property taxation is covered in less detail. Unfortunately basic information is currently not available for some of the countries. The study of property taxation in Europe offers special challenges because each country has a different definition of land and property and a different approach to the local property taxation. In the majority of the countries the term "property" will include both land and buildings, but it may also be extended to the plant and machinery as well as a variety of chattels. For example in Macedonia, the property tax includes cars, boats and airplanes. In some countries separate taxes may be levied in respect of the land and property (buildings) elements of a holding. The definition of land includes not only the land itself, but also any fixtures (buildings) attached to it, and extends to anything growing on the land. The definition will also include anything under the surface of the land (minerals) as well as the rights over the land, such as a right for an electricity cable, which crosses the airspace. In Denmark, for example, separate taxes may be levied on the land and property elements of a single holding. European countries have 61 different forms of local taxation. Most are based on the annual value, usually assessed on a capital or rental basis, and are payable annually. While most countries tax the sale of property at the state level, the Czech Republic, Italy, Portugal, Slovakia and Spain levy such taxes locally. Each country, except Malta, operates some form of annual property tax on the use or occupation of land and/or property, usually levied at the local level, and the revenues are allocated for the provision of local services.

Over the last 10 years France, Denmark, Germany, the Netherlands, Belgium, the United Kingdom and the Republic of Ireland have either completed or are in the process of completing substantial reforms of their taxa- 
tion systems. Other countries have undertaken rather minor reforms. Even some emerging democracies are reviewing and reforming their relatively new taxation systems in the light of changes elsewhere. No individual tax exists in isolation, and all are affected by larger fiscal, economic and political developments. The reform of one tax will often have consequential effects on others, and property taxation in all its forms is no exception.

Not all countries have adopted some form of annual property taxation, though its adoption in one form or another is quite widespread. Malta and Norway do not have annual property taxation. It is not possible, nor necessary, to provide an exhaustive definition of such a tax which would cover all eventualities. However, for the purpose of the research, the concept of the local property taxation has been employed in the meaning of an annual tax on the use or occupation of land and/or property usually levied at the local level, the revenues of which are allocated for the provision of local services. Some flexibility in the application of the definition needs to take place to recognize that often due to the size of a country the tax may actually be levied at a national level with the revenues remitted to the local level. Furthermore, countries, such as Spain, Portugal and Italy, levy a local tax on the sale of property, and France and Switzerland levy local taxes that include a profit tax.

\subsection{Taxpayer and Sources of Valuation Information}

The majority of property taxes are payable by the owner. Of the 51 taxes in Europe, 29 identify the owner as the taxpayer and 12 are paid by the occupier; the remaining 10 are sales-based taxes (see Table 2). The occupier figure was distorted because the United Kingdom accounted for 50 percent of this figure due to differences in the implementation of its local taxes. In the Netherlands both parties can be taxed by different amounts.

Many countries have some form of comput- erized cadastral system to record property-related information, and, as a part of the assessment process, different governmental levels usually exchange information. The nature and implementation of such systems vary considerably, from a series of different registers administered at various governmental levels to a single register administered nationally. The rights of a taxpayer to centrally held information also differ among countries. Some provide no rights to any information, while others notify whenever a new valuation or alteration is made. In some cases, valuation and comparable evidence may be made available at the request of the taxpayer [9].

\subsection{Bases of Valuation and Revaluation of the Tax Base}

Three alternative approaches to the valuation bases are used most frequently. The Capital Value Approach is normally based on the open market value of the property on a specified baseline date, which may be a current date, such as the start of the tax year. Sweden designates a date two years before the tax year. This approach has the advantage of giving the valuation authorities more time to consider all the evidence available before arriving at their final valuations. The open market value is usually defined on the basis of the best and/or highest property value. The Rental Value Approach is based on the open market rental value on a specified date. England, Wales, Scotland and the Republic of Ireland specify a baseline date some time before the new values come into effect, as in Sweden. The open market rental value may be restricted by assumptions as to changes of use and alterations. The rationale is that the tax is levied on the occupier, and the amount of tax is based on the current use of the property, not its potential value. Property not normally bought and sold in the market requires alternative approaches to valuation. For example, the use of a revenue (or accounts) approach has been adopted in England and Wales for many types of leisure-related prop- 
erty, and its use is expected to increase. The cost approach, related to the cost of construction, is also widely accepted in England and Wales and in other European countries. The Overall or Unit Approach relates to a property size. The tax is levied at a prescribed rate per square meters or per unit, which may vary depending on the predominant use of the property. These rates may be loosely based on rental or capital values, but an arbitrary rate fixed by the appropriate taxation authority is more common. In 1997 the Netherlands moved away from such a system in favour of a market-related capital value approach. Many new democracies have adopted the unit approach due to a lack of property information, a limited and restricted property market, and insufficient resources to enable the development of alternative systems. It is anticipated that many of these countries will move to a value-based system when resources and circumstances permit. A number of other approaches are used under special circumstances. One is the capital value banding approach adopted for the valuation of residential property by the Council Tax in England, Wales and Scotland. This approach rather ascribes property to various value bands than gives precise valuation of each individual property. Another example is the local business tax, which includes the value of the property plus a percentage of salaries, in the case of France, and business profit, in the case of Spain and Switzerland.

One of the key factors in examining European property tax systems is whether the valuations on which the tax is charged are up-todate. Our research identified a very mixed picture: some countries have not revalued their tax bases for many years and others undertake revaluations regularly, every four or five years. Many countries have either no provision for regular revaluations or have postponed revaluations so often that their tax base bears little resemblance to the current market values (see Table 2) [1, 2, 7].

\subsection{Indexation, Exemptions and Relieves, Appeal Systems and Tax Collection and Payment}

Many countries have attempted to overcome the problems associated with infrequent revaluations by some form of indexation. Those countries performing annual revaluations may implement them through actual annual revaluations, indexation of an earlier revaluation or self-assessment declarations by the taxpayer. While annual indexation between regular revaluations every few years may ensure a relatively accurate tax base, its use becomes more questionable when the base has not been updated for 10 or 20 years. The situation is far worse in countries where the property market is changing rapidly, especially in major cities and towns. Any adopted index needs to be closely related to the property market in that location and to the specific property type. In most cases, however, the index is a single figure applied across the entire country and for all types of property.

Exemptions can be considered from two viewpoints: the nature of the property or the nature of the taxpayer. In addition, some countries have introduced arrangements that place a ceiling on the amount of tax payable. Some common features relating to the types of properties for which some form of relief may be granted are:

- land owned by the state and used for the provision of public services, such as schools, hospitals, cemeteries etc., if usually exempt or excluded from the tax legislation;

- land and property used for religious purposes;

- historic land and buildings;

- agricultural land.

Relief to taxpayers takes many forms and can include:

- relief to persons of retirement age;

- relief to disabled persons;

- relief of a percentage of the tax to certain owner-occupiers or remittance of an initial amount of the tax. 
Table 2. Annual Land and Property taxes - European Comparison

\begin{tabular}{|c|c|c|c|c|c|c|c|c|c|c|c|}
\hline \multirow[t]{2}{*}{ Country } & \multirow[t]{2}{*}{ Tax } & \multicolumn{3}{|c|}{$\begin{array}{l}\text { Taxable } \\
\text { Item }\end{array}$} & \multicolumn{3}{|c|}{ Taxpayer } & \multicolumn{3}{|c|}{ Basis of Valuation } & \multirow[t]{2}{*}{ Revaluations } \\
\hline & & 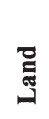 & : & 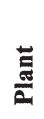 & है & ठ் & 吾 & 焉 & 吾 & 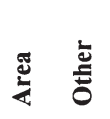 & \\
\hline Austria & Real Estate tax & $\checkmark$ & $\checkmark$ & & $\checkmark$ & & & & & $\checkmark$ & $\begin{array}{l}\text { Mid } 1980 \text { 's, but some attempt has been } \\
\text { made to update the valuation base by } \\
\text { the use of indexation. However values } \\
\text { still fall well short of the market value } \\
\text { of property even after the application of } \\
\text { indexation. }\end{array}$ \\
\hline Belgium & Revenue cadastral & $\checkmark$ & $\checkmark$ & $\checkmark$ & & $\checkmark$ & & $\checkmark$ & & & $\begin{array}{l}10 \text { years, but revaluations of } 1990 \text { and } \\
2000 \text { have been postponed. } \\
\text { Interim use of indexation adopted }\end{array}$ \\
\hline \multirow[t]{3}{*}{ Denmark } & Country real estate tax & $\checkmark$ & $x$ & & $\checkmark$ & & & & $\checkmark$ & & 4 years with annual indexation \\
\hline & Municipal real estate tax & $\checkmark$ & $x$ & & $\checkmark$ & & & & $\checkmark$ & & 4 years with annual indexation \\
\hline & $\begin{array}{l}\text { Municipal real estate tax } \\
\text { on commercial buildings }\end{array}$ & $x$ & $\checkmark$ & & $\checkmark$ & & & & $\checkmark$ & & 4 years with annual indexation \\
\hline Finland & Real property tax & $\checkmark$ & $\checkmark$ & & $\checkmark$ & & & & $\checkmark$ & & Annual \\
\hline \multirow[t]{3}{*}{ France } & Property tax & $\checkmark$ & $\begin{array}{l}\checkmark \\
1\end{array}$ & $x$ & & $\checkmark$ & & $\checkmark$ & & & $\begin{array}{l}3 \text { years, but revaluations have been } \\
\text { postponed and an annual indexation } \\
\text { adopted in the interim }\end{array}$ \\
\hline & Property and Land tax & $\checkmark$ & $\checkmark$ & & $\checkmark$ & & & $\checkmark$ & & & $\begin{array}{l}3 \text { years, but revaluations have been } \\
\text { postponed and an annual indexation } \\
\text { adopted in the interim }\end{array}$ \\
\hline & Business tax & & & $\checkmark$ & $\checkmark$ & & $\checkmark$ & & $\checkmark$ & & $\begin{array}{l}3 \text { years, but revaluations have been } \\
\text { postponed and an annual indexation } \\
\text { adopted in the interim }\end{array}$ \\
\hline Germany & Real estate tax & $\checkmark$ & $\checkmark$ & & $\checkmark$ & & & & $\checkmark$ & & $\begin{array}{l}6 \text { years, but no revaluations have taken } \\
\text { place since } 1964\end{array}$ \\
\hline Iceland & Real property tax & $\checkmark$ & $\checkmark$ & & $\checkmark$ & & & & $\checkmark$ & & Not specified \\
\hline \multirow[t]{2}{*}{ Ireland } & $\begin{array}{l}\text { Rates (Pre Valuation Act } \\
\text { 2001) }\end{array}$ & $\checkmark$ & $\checkmark$ & $\checkmark$ & & $\checkmark$ & & $\checkmark$ & & & 5 year rolling revaluations \\
\hline & $\begin{array}{l}\text { Rates (Post Valuation } \\
\text { Act 2001) }\end{array}$ & $\checkmark$ & $\checkmark$ & $\checkmark$ & & $\checkmark$ & & $\checkmark$ & & & $5 / 10$ year rolling revaluations \\
\hline Italy & $\begin{array}{l}\text { Communal Real Estate } \\
\text { Tax }\end{array}$ & $\checkmark$ & $\checkmark$ & & $\checkmark$ & & & $\checkmark$ & & & Not specified \\
\hline Luxembourg & & $\checkmark$ & $\checkmark$ & & $\checkmark$ & & & & $\checkmark$ & & \\
\hline \multirow[t]{2}{*}{ The Netherlands } & $\begin{array}{l}\text { Onroerend } \\
\text { Goedbbelasting (OGB) }\end{array}$ & $\checkmark$ & $\checkmark$ & & & & $\checkmark$ & & $\checkmark$ & & 4 year rolling revaluation \\
\hline & Waterchap levy & $\checkmark$ & $\checkmark$ & & $\checkmark$ & $\checkmark$ & & & $\checkmark$ & & \\
\hline Portugal & $\begin{array}{l}\text { Immoveable Property } \\
\text { Tax }\end{array}$ & $\checkmark$ & $\checkmark$ & & $\checkmark$ & & & $\checkmark$ & $\begin{array}{l}\checkmark \\
2 \\
\end{array}$ & & Annual indexation \\
\hline Spain & Local property tax & $\checkmark$ & $\checkmark$ & & $\checkmark$ & & & & $\checkmark$ & & Annual indexation \\
\hline Sweden & & & $\checkmark$ & & & $\checkmark$ & & & $\checkmark$ & & 4 year rolling revaluation \\
\hline Switzerland & Municipal Business Tax & $\checkmark$ & $\checkmark$ & & & $\checkmark$ & & & & $\checkmark$ & Annual - based on rent and profit \\
\hline \multirow{2}{*}{$\begin{array}{l}\text { England and } \\
\text { Wales }\end{array}$} & Non domestic rates & $\checkmark$ & $\checkmark$ & $\checkmark$ & & $\checkmark$ & & $\checkmark$ & & & 5 years \\
\hline & Council Tax & $x$ & $\checkmark$ & $x$ & & $\checkmark$ & & & $\checkmark$ & & Not prescribed \\
\hline \multirow[t]{2}{*}{ Scotland } & Non domestic rates & $\checkmark$ & $\checkmark$ & $\checkmark$ & & $\checkmark$ & & $\checkmark$ & & & 5 years \\
\hline & Council Tax & $x$ & $\checkmark$ & $x$ & & $\checkmark$ & & & $\checkmark$ & & Not prescribed \\
\hline Northern Ireland & Rates & $\checkmark$ & $\checkmark$ & $\checkmark$ & & $\checkmark$ & & $\checkmark$ & & & \\
\hline
\end{tabular}

An $X$ indicated that the item is not subject to the tax

1 - Applies to residential buildings only

2 - Tax is based on a capitalized rental value 
Most countries have a system by which a taxpayer may challenge the tax assessment or valuation, although that action generally does not defer the payment of the tax. In some cases the first step is an informal approach to the authority, which may be able to resolve the dispute without the need for more formal action. Where a formal approach is adopted, the appeal may be dealt with as a part of the general tax appeal process through the normal tax tribunals and courts, or it may be handled beyond the normal tax system, often in courts and tribunals established for that purpose.

In many countries taxes are collected by the national tax authority, often as a part of the income tax process. This method has the advantage of being linked with national exemptions and benefits; the resulting tax is usually payable over the whole tax year. Under the second common method, the tax is paid directly to the relevant taxing authority, sometimes in installments [2].

\section{LITHUANIA AND OTHER BALTIC COUNTRIES}

The fall of Soviet communism launched an era of reform throughout Central and Eastern Europe. Countries that came to be labeled economies in transition from command to market systems created institutions that now provide the foundations for pluralistic, democratic regimes. Among these reforms, the process of decentralization has been focal: it entailed the devolution of fiscal powers and responsibilities from central to local governments.

As Central and Eastern European countries have developed new fiscal policies and new approaches to property rights during the past decade, property taxation has taken on new importance, serving not only as a revenue instrument, but also as an adjunct to decentralization and privatization. Despite the complex and varied national differences in this region, common issues have emerged with regard to property-based taxes. A number of consider- ations led to the designation of such taxes as local revenue sources. An immovable tax base offers the possibility of independent local revenue, even as times of fiscal stringency at the national government levels dramatize the importance of some measure of fiscal autonomy. Moreover, the goal of eventual accession to the European Union and other trade arenas encourages the development of taxes not subject to international competition. Efforts to implement land and building taxes have been confronted with two primary difficulties. First, the absence of developed property markets requires a choice among formulary values, price approximations, and non-value means of allocating the tax burden. A lack of reliable market prices together with a legacy of officially determined price levels has often encouraged the assignment of specific, sometimes arbitrary, property values for the tax purposes. Second, periods of financial hardship present special problems in imposing taxes on assets that do not produce income to pay the tax. This dilemma has left many property taxes at nominal levels. With regard to these difficulties, it is particularly significant that many of these nations have either adopted or are seriously considering some form of value-based taxation of immovable property as a source of the local government finance [3, 4].

The Baltic countries of Estonia, Latvia and Lithuania have been in the forefront of implementing value-based taxes on land. Estonia was the first of these new independent states to recognize the benefits of land taxation and to introduce a value-based land tax in 1993, followed by Latvia in 1998. Lithuania has been a leader in integrating and unifying real estate cadastral, registration and valuation systems to strengthen emerging real estate markets and support real property taxation. Progress toward value-based taxation in Lithuania began with the integration of real estate administrative units and the development of an automated central database of real property information in a self-funded state 
enterprise known as the State Enterprise Centre of Registers (SECR). In 2001 the Ministry of Finance funded the SECR to plan and develop a mass valuation system in preparation for the anticipated passage of the laws that will introduce value-based taxation of real property throughout Lithuania. The first phase of this program involved the development of land value maps that were completed and made public in 2003 [6].

The Republic of Lithuania, which declared its independence from the USSR in 1990, is the largest and the southernmost of the Baltic countries, with a total area of $65,300 \mathrm{sq}$. $\mathrm{km}$. and a population of 3.5 million. Although the other Baltic countries introduced market value-based land taxes earlier, Lithuania anticipates that its up-to-date real property information system and administration network, managed by the State Enterprise Centre of Registers (SECR), will speed its implementation. The SECR has been assigned the task of valuing property for taxation, and for this purpose it will utilize its computerized real property information system of land and building data.

Tax systems in Lithuania, established in the early post-Soviet period, are gradually being reformed to accommodate the development of democratic institutions and market economies and to advance negotiations for the accession to the European Union. The Lithuanian Governmental Action Program for 2001-2004 gave the priority to the introduction of market value-based taxes on land and buildings, contemplating an extended tax base and a greater role of the local government in the fiscal decision-making. Taxation measures are discussed below.

\subsection{Current Taxes on Land and Buildings}

Currently there are two national taxes: a 1.5 percent land tax paid by landowners and 1.0 percent property tax on the value of property (excluding land) paid by corporations and other legal entities (see Table 3). The tax proceeds are returned to the municipalities, where in 2001 they provided on average just over 8 percent of municipal budgets. The revenue from the property tax was nearly 10 times higher than the revenue from the land tax, and has increased annually, representing 2.3 percent of national budget revenues. Neither tax has a market value base at present, although some market elements have been introduced gradually in the land tax base [6].

\subsection{Sales Data and Mass Valuation Pilot Project}

The SECR has been collecting real property sales information since 1998, and there are a sufficient number of transactions of flats, garages and land parcels to support mass valuation modeling based on the market principles. The SECR has created a databank of real property sales, and when a new real property unit is formed, it is inventoried and described in the Real Property Cadastre, and all property rights are registered in the Real Property Register. At the conclusion of a transaction, a new owner registers the ownership in the register, but the data in the cadastre are not changed. When the transaction is registered, the sale price indicated in the purchase-and-sale agreement is recorded into the database, allowing the price information to be supplemented by descriptive (cadastral) attributes [6].

Table 3. Annual Land and Property taxes - Lithuania (at the moment)

\begin{tabular}{|c|c|c|c|c|c|c|c|c|c|c|c|}
\hline \multirow[t]{2}{*}{ Tax } & \multicolumn{3}{|c|}{ Taxable Item } & \multicolumn{3}{|c|}{ Taxpayer } & \multicolumn{4}{|c|}{ Basis of Valuation } & \multirow[t]{2}{*}{ Revaluations } \\
\hline & Land & Building & Plant & Owner & Occ & Both & Rental & Capital & Area & Other & \\
\hline Land tax & $\checkmark$ & & & $\checkmark$ & & & & $\checkmark$ & & & 5 years \\
\hline Property tax & & $\checkmark$ & & $\checkmark$ & & & & $\checkmark$ & & & 5 years \\
\hline
\end{tabular}


To prepare for the implementation of the value-based real property taxation, the Ministry of Finance assigned the SECR the task of undertaking a pilot project using mass valuation techniques. The results will be presented to the Ministry of Finance and other interested state institutions.

The SECR aims at completing the development of a real property mass valuation system in order to achieve the following goals:

- introduce data analysis and mass valuation technologies into practice;

- prepare property mass valuation methods corresponding to the Lithuanian conditions;

- train specialists to carry out mass valuation;

- propose improvements to the real property database and adaptations for the mass valuation purposes.

To conclude, the SECR will be able to analyze various possibilities for introducing a computer-assisted mass appraisal (CAMA) system in Lithuania, and to prepare proposals regarding ad valorem property tax administration and relevant institutional infrastructure development. The project involves 40 property assessors from both the central and branch offices of the SECR, who have been trained by specialists within the SECR and international experts, including the Lincoln Institute, Organization for Economic Co-operation (OECD), Sweden survey and the Finnish National Land Survey.

Property valuations have been nearly completed in the 11 municipalities selected as demonstration projects, one located in the territory of each branch office of the SECR. The experience gained from these pilot projects will be valuable in extending the valuation throughout the entire country [4].

\subsection{Current issues: The bill on the real property tax in Lithuania}

Recently proposed, the amended bill on the real estate tax is expected to be approved after the parliamentary elections in Lithuania. It provides for the introduction of the real estate tax for individual and commercial registered property owners.

The main purposes of the introduction of this bill were:

1. To guarantee independent revenue sources for the local authorities;

2. To aggregate land and buildings taxation in one law.

The second purpose seems to be inevitable. Lithuania needs a single law to regulate its property taxation. Recently different laws regulated actually one object - real property.

Under the bill the property tax will be levied on private and commercial taxable property owners. This provision is under discussion now. The widely quoted argument that the tax affects the rich and their wealth is spurious. Possession of property is not necessarily an indication of luxury or affluence. People may acquire property through inheritance or restitution, or they may purchase it with borrowed money. For big families, a large dwelling is not a luxury but a necessity. Large houses may be occupied by several generations, so the real estate tax will force people to parcel their property, thus causing personal and formal difficulties. Under the law private flats will become taxable object as well.

The law guarantees some deductions though. The bill provides that private owners living in their property are entitled to some exemptions and deductions. The amounts exempted vary in each municipality: Klaipeda 105.700 Lt, Neringa - 160.900 Lt, Vilnius 150.000 Lt, Trakai - 108.000 Lt, etc. The greatest exemptions are set for prestigious municipalities.

Under this provision low-valued private flats are not subject to taxation in this way. It should be noticed that deductions on land are not proposed.

The base of the introduced property tax is the capital market value of land and buildings, and the rate varies from 0.5 to 1.5 percent. The actual tax rate is set by each municipality. 1 percent variance brings some uncertainty 
to taxation, but, on the other hand, it depends on municipality's needs.

Valuation standards will be set by government for the property taxation purposes. But mass valuation is likely to become the future valuation methodology. Land already is valued by mass valuation methods, the same methods can be used for valuation of buildings as well. Appraisers are under the choice of government. It is possible that private appraisers will be involved in this process too. Anyway, the overall aim is to achieve a correct total taxable value of the property, which must match the real market value, and to collect enough revenues from property taxes to grant municipality's needs.

\section{DRAWBACKS OF THE LITHUANIAN REAL ESTATE TAXATION SYSTEM. PROPOSALS FOR THE SYSTEM IMPROVEMENT}

The Lithuanian real estate taxation system still remains an outstanding issue. A positive step is an attempt to devise a new system by way of adoption of a new real estate tax law, pursuing regulation of taxation of real estate held by the proprietary rights, including land, by a single law. The latter taxation system would be only beneficial, as currently there operate a number of laws regulating the taxation of the same object - real estate. Notwithstanding this, the bill in question, having faced strong opposition of the society, was not enforced on 1 January 2003 and remains an outstanding issue. This suggests its underlying faults, the application of the real estate model of the United States in the development of a new taxation system to be distinguished above of all. The United States differ from Lithuania not only in its size and legal system but also in its living standards. Moreover, the latter country has a long-standing practice of the real estate taxation. Therefore the tax is common for the local inhabitants, though its abolition has been the subject of discussions for years.

The introduction of the new real estate tax may be subjected to criticism in many aspects:

1. The real estate tax must be paid without having real sources for paying it. The tax thus reduces people's real income.

A situation when an individual has some property but not always income is very typical of Lithuania, where acquisition of real estate has traditionally been regarded as a safe investment in the context of inflation and instability of the banking sector. If signed into law, the real estate tax would increase people's sense of social insecurity and reduce real income. It should be noted that people pay taxes on all personal income, including income derived from real estate.

2. Calculation of a taxable value is costly, inaccurate and unrealistic. The effective rate of the real estate tax will always differ from the nominal one. The development of a new more realistic methodology of real estate valuation should entail the consideration of the valuation issue.

3. The real estate tax infringes on the fundamentals of private ownership. It will lead to a decline of large, fine buildings.

The property taxation deters owners from eventual investing in their property, which entails greater burden of taxes. Property development is a crucial issue for Lithuania, as a reinstated country, after its accession to the European Union. Therefore, there may be proposed the two alternatives: to impose land tax alone or restrict the growth of tax value.

4. The real estate tax will widen, rather than even out, the differences in taxation regimes for corporations and individuals.

One frequently cited argument for the real estate tax is that it will help even out tax conditions for corporations and individuals. But these conditions cannot be uniform given that corporations use assets for business activity, whereas individuals do for residential purposes. Enterprises pay the real estate tax before corporate tax, while individuals pay taxes on all income. This means that they pay the real estate tax from income that has already been taxed once. Therefore, the tax regimes should 
be evened out by abolishing the real estate tax for corporations rather than imposing the tax on individuals.

5. The introduction of the real estate tax will result in double income taxation.

Given that all personal income is taxed without any deductions, the real estate tax will be paid from income already taxed once. Double taxation is one of the biggest defects of the tax system, making it irrational and non-transparent.

6. The true incidence of the real estate tax will be shifted to other categories of taxpayers than those envisaged by the law.

The incidence of the real estate tax can be shifted so that the tax will not be paid by the owners. In this case, the best illustration of the tax incidence is rent. The owner shifts the real estate tax onto a tenant by increasing the rent. Thus, the tax burden falls not on large property owners but on those who do not possess any property at all and are forced to rent it. Similarly, it will injure middle-income individuals who use taxable property for their own needs.

7. The real estate tax is unfair as it results in progressive or regressive income taxation, depending on who the real taxpayer is. The tax is not neutral either, as one type of property is picked from among a range of assets and is made subject to specific tax rules. The real estate tax, in its essence, cannot ensure tax equality because corporations and individuals use assets on a different basis and for different purposes. The effectiveness of administering the real estate tax, compared to other taxes, will be much lower.

8. The real estate tax will be targeted not only at luxury.

The widely quoted argument that the tax affects the rich and their wealth is entirely spurious. Possession of property is not necessarily an indication of luxury or affluence. People may acquire property through inheritance or restitution, or they may purchase it with borrowed money. For big families, a large dwelling is not a luxury but a necessity. Large houses may be occupied by several generations, so the real estate tax will force people to parcel their property, thus causing personal and formal difficulties.

9. The real estate tax has a negative effect on the real estate and mortgage markets.

The real estate tax will lead to a drop in prices of immovable property. The real estate market will be faced with diminishing liquidity. Under such conditions, one will have to mortgage more assets to get a loan from a bank. Consequently, credits will become more expensive, even if interest rates do not change. This will most heavily burden on novice entrepreneurs and family businesses.

10. One of the objectives pursued in the new bill is vesting of greater powers with the municipalities. In order to reconcile the financial resources of the Lithuanian local bodies with their statutory obligations, it is expedient to develop fiscal decentralization, i.e. to vest greater powers with the municipalities in the establishment of relevant taxes.

Nevertheless, in respect of the experience of the United States, such an objective is rather debatable. Lithuania, as compared to the United States, is a small country, and there arises the previously discussed issue - whether such a great fiscal power is requisite for the municipal bodies. There also emerge the issues of the multi-stage taxation system. Centralized revenue allocation might possibly suffice, provided that the system is flexible and fair.

Substantiation of the arguments against the real estate tax should also involve evaluation of the situation in Denmark, where the real estate tax system was subjected to reforms in 1998.

A major factor influencing the housing market in the recent years has been the uncertainty induced by the announcement of budgetary proposals in 1998 that the tax burden on property owners was to increase. These measures were finally introduced in 2000 as a part of a broader reform of the tax system and are generally known as the 'Whitsun Package' tax reforms. The full measures were then 
gradually phased in over a two year's period. Traditionally, homeowners could claim relief in their tax returns for the mortgage and other interest charges they had incurred during the tax year. The mortgage tax relief, however, was offset by a tax on imputed rental income. The latter was set at a low rate, so that overall homeownership had a tax benefit over other forms of investment. The imputed rent tax was converted in the tax reforms to a local property tax set at $0.8 \%$ of re-assessed property values for most owners and at $1 \%$ for those buying after July 1, 1998. Furthermore, a higher rate of $3 \%$ was set for more expensive property valued at above DKK 2.815.000,00. Changes were also made to mortgage interest tax relief by capping it at the $32 \%$ tax band, which is important in a country with some of the highest marginal tax rates in the EU. Overall, these tax changes represented a significant new tax burden for homeowners, although its precise impact is complex as it varies depending on household incomes and borrowings.

Because the overall Whitsun Package had substantial implications for homeowners' tax exposures, it was forecast at the time of its implementation that house prices would be 15$20 \%$ lower than they would have otherwise been. The two and a half years between the announcement of the reform and its enactment in 2001, consequently, created significant adjustment problems. As overall housing demand has been growing, the tax reform has actually resulted in the house price growth below what would have otherwise occurred, because purchasers have had to take the financial implications of the reforms into account in their house price bids. It was feared that the tax reforms would lead to sharp falls in house prices.

Now Denmark has tax and benefit rules that combine with other housing regulations to create one of the most complex and distorted housing systems in Europe. Yet, there is a great deal of political support for the status quo and even for a further enhancing of special subsidies and tax breaks. Change is also inhibited by the likely severe adjustment costs that would be incurred by particular households in a shift towards a more rational system. Yet, there is a growing chorus of complaints about the inefficiencies and inequities led by a number of influential reports of economic institutions.

The formation of the real estate tax system is a complex process regardless of the country it takes place. The issue often falls subject to debates generally due to the taxation object real estate, which is primary possession of many of people, with the peculiar feature of long-lasting. That is why it is necessary to look for other ways of establishing fairer, more efficient, correct and human relationship between the state and Lithuanian taxpayers. It would be expedient to substitute the real estate tax with the land value tax, which would foster investments, activate new constructions, increase supply of land parcels and force down the growth of their prices. Germany is planning to shift to such a real estate taxation system. The following advantages of land taxation may be accentuated:

1. Municipalities fall short of funds to cover the costs of the housing estate infrastructure, and as a result they are unable to allot land for development purposes. The land value tax may facilitate financing of means of urban construction, as it is levied as from the starting point of the construction, notwithstanding the progress of the construction by the private investors. Therefore taxes are collected at an early stage, revenue is more secured, and the costs of land development for the construction purpose are directly incurred by the beneficiaries.

2. Solutions of territorial planning are frequently distorted due to vested interests. The land value tax may enhance the neutrality of planning. The introduction of the land value tax shall cause its capitalization and reduction in land prices. As a result, influenced by planning value increments and profit gained by the owners, who maintained their parcels expecting value increments due to the future planning, will drop. This will minimize the pretext of affecting the decision-making on the issues 
of territorial planning out of self-seeking motives, and ensure the higher objectivity of planning.

3. Development land is often unused or is not made the best use of, as the costs of uneconomic use are latent. In this case the land value tax will have a positive effect, since regular tax payments make the costs of uneconomic use of land become apparent. This is especially applicable to the owners who fail to make economic use of their possession out of ignorance of for other reasons. The land value tax, payable from the land value and eventual revenue in that locality, would foster the use of land.

4. Improvement of valuation accuracy. The current assessment of tax values is faulty to such an extent that the land value tax faces no criticism in the country. Assessment of the land value provides with more accurate results than any other mass building valuation.

5. Reduction in the land value tax assessment. Costs of the land value tax assessment will be minimized as compared to those entailed by the assessment of the real estate tax value.

6. The land value tax plays a great role in the struggle against speculation with land, though it does not completely erase the problems and merely alleviates them. The partial curbing of the growth of values almost eliminates the pivotal speculation motive to benefit from the price fluctuation. The land value tax ensures the attribution of the infrastructure costs to their recipients, also supporting fair urban planning. Long-term capital investment in land will no longer remain so attractive, which will curb speculation with land.

7. Actuation of the most efficient economic use. The land value tax will stimulate land owners to take advantage of opportunities made available by planning and actualize the best most efficient economic use.

8. Mobilization of the development land, reactivation of the use of old industrial localities. Blank parcels would be levied by the land value tax rather than the real estate tax. As a result, this would stimulate prompt develop- ment of newly allotted development lots and blank parcels. The latter effect of the land value tax will not be enforced or will be tenuously enacted in old industrial localities with old industrial buildings and constructions.

9. Densification of urban developments. With the introduction of the land value tax, as before, every parcel shall be estimated a maximum development density. The latter tax will stimulate the actualization of such eventual development.

10. Maintenance and restoration of towns. The land value tax will also foster maintenance and renovation of available constructions in order to extend the term of profit gaining. Of course, it is possible that the buildings still satisfactory in constructional terms, but unprofitable economically may be subjected to demolition sooner than usually accepted and replaced by the new ones.

11. The ratio of the city and the surrounding land. A more intensive use of land caused by the land value tax will diminish demand for new construction development land. In the interim the growth of the real estate tax rate escalates the space of the city, which, in its turn, stimulates the expansion of the city, whereas the substitution of the real estate tax by the land value tax will influence the contraction of the urban area. Demand for extensively used development land will dramatically diminish. The owners of the parcels located in prestigious localities of the city, gaining small profit as per area unit, will be motivated to move to the areas of a smaller value, which will give rise to increasing demand for the suburban development land.

12. The land value tax, contrary to many other taxes, will not be levied on the revenue and profit acquired from private economic activity. By contrast, buildings and investment will be exempt from taxation. The land value tax will also improve the distribution of production factor and land. Investment will be encouraged, the intensity of the capital of the land use will grow, which will have an overall positive on economy. 
13. The land value tax promotes intensive use of land and the political objectives of the environment to minimize the area used for township developments. An extensive use of development land for the purpose of housing development and enterprise will entail higher costs. Due to the land tax, it will be economically significant to reduce the area of the used land, for instance by way of construction of higher buildings. As a result, this will increase the awareness of nature and landscape protection. The decrease in a number of roadways and power consumption will follow the densification of construction developments.

\section{CONCLUSIONS}

The property tax is the single most important source of tax revenue for most local governments in the United States. The basic principles of property valuation and administration are well established in this country. Significant progress has been made in the last fifteen years in increasing the professionalism of assessing personnel through education and certification programs, in developing techniques for mass appraisal, and in making use of computers for greater accuracy and efficiency. It can be concluded that the property taxation is approved by the society in the United States, as fewer than 10 percent of property owners appeal their taxes.

European countries are constantly reviewing their tax systems and adopting the best features of other systems. This presents special challenges to the survey, but also enhances its potential impact by allowing the comparative analysis to influence the new legislation. One very important conclusion is the significance of keeping the tax base up-to-date. This not only simplifies the entire valuation and collection process but also ensures a tax base that is more acceptable and understandable for taxpayers.

Not all European countries have adopted some form of annual property taxation, notwithstanding that its adoption in one form or another is quite widespread. The majority of property taxes are payable by the owner. Many countries have some form of computerized cadastral system to record property-related information, and as a part of the assessment process different governmental levels usually exchange information. In many countries taxes are collected by the national tax authority, often as a part of the income tax process.

The Baltic countries of Estonia, Latvia and Lithuania have been in the forefront of implementing value-based taxes on land. Progress toward value-based taxation in Lithuania began with the integration of real property administrative units and the development of an automated central database of real property information in a self-funded state enterprise known as the State Centre of Registers (SECR). Tax systems in Lithuania, established in the early post-Soviet period, are gradually being reformed to accommodate development of democratic institutions and market economies, and to advance negotiations of accession to the European Union. The recently proposed bill on the real estate tax provides for the introduction of the real estate tax for individual and commercial registered property owners. Mass valuation is likely to become the future valuation methodology. Land is already valued by mass valuation methods, the same methods can be applied in valuation of buildings as well. It can be concluded that the future property tax in Lithuania will fulfill taxation systems adopted in other European countries and the United States.

It can be summarized that most European countries levy property taxes on both major types of real estate - land and buildings. The United States and Lithuania are not an exception in this case. This way of taxation gives more revenues for the local governments; therefore it can be approved easily. Only few countries all over the world can afford single land taxation to support their functions.

The payment of property taxes is incumbent on the occupier or owner in most countries. It can be noticed that responsibility generally 
rests with the property owner. Only the Netherlands tax both - the occupier and owner of the real estate.

The tax bases represented among the countries surveyed include the capital market value or simplified valuation models based on the market values, the annual rental value and area-based models. The capital value is the most popular taxable value in many aforementioned countries. Where taxes are collected on the basis of the market value, valuation is primarily determined according to the highest and best economic use of the property, but may in some jurisdictions or for certain categories of property be restricted to valuation according to the current use of the property.

Revenues from the property taxation primarily depend on the accuracy of valuation. Most countries have recently begun using computerized mass valuation systems. Lithuania did a great work implementing this method of modern valuation of land.

\section{REFERENCES}

[1] M. Ball, RICS European housing review, 2003, http://www.rics.org/research/ehr

[2] P. K. Brown, M. A. Hepworth, A Study of Euro- pean Land Tax systems, Working Paper, Lincoln Institute of Land Policy, February 2002, http://www.lincolninst.edu

[3] J. H. Malme, Mass Valuation for Land in Transitional Economies, Land Lines, 16(2), 2004, Lincoln Institute of Land Policy, http:// www.lincolninst.edu

[4] J. H. Malme, J. M. Youngman, The Development of Property Taxation in Economies in Transition: Case Studies from Central and Eastern Europe, Washington, DC, The World Bank, 2001, http://www.lincolninst.edu

[5] A. Paugam, Ad valorem property taxation and transition economies, The World Bank working paper Number 9, 1999.

[6] K. Sabaliauskas, A. Aleksienè, Progress Toward Value - Based Taxation of Real Property in Lithuania, Land Lines, 14(4), 2002, Lincoln Institute of Land Policy, http:// www.lincolninst.edu

[7] E. Weiss, Replacing a 'Combined Tax on Land and Buildings' with a Simplified 'Land Value Tax' in the Federal Republic of Germany, International Journal of Strategic Property Management, 8(4), 2004, p. 241-245.

[8] A. Woorely, Property tax principles and practice, Lincoln institute of land policy, 1998.

[9] J. Youngman, J. H. Malme, An International Survey of Taxes on Land and Buildings, Lincoln Institute of land policy, 1994. $223 \mathrm{p}$.

\section{SANTRAUKA}

\section{LIETUVOS NEKILNOJAMOJO TURTO APMOKESTINIMO SISTEMA UŽSIENIO ŠALIŲ KONTEKSTE} Vida MALIENĖ, Daiva CIBULSKIENĖ, Virginija GURSKIENĖ

Analizuojama dabartinè bei planuojama priimti nauja nekilnojamojo turto apmokestinimo sistema Lietuvoje, aiškinami naujai siūlomos sistemos privalumai ir trūkumai, atliekama JAV ir Europos šalių lyginamoji analizè. Remiantis gautais analizès rezultatais bei užsienio patirtimi, pateikiami siūlymai Lietuvos nekilnojamojo turto apmokestinimo sistemai tobulinti. Analizuojama nekilnojamojo turto mokesčiu bazè, nagrinėjamos šiuo metu igyvendinamos mokesčiu reformos, vertinamas pasikeitimų poveikis nekilnojamojo turto rinkai. Pateikiama keletas pagrindinių bendrų visoms nagrinėjamoms šalims nekilnojamojo turto mokesčių sistemos aspektų - mokéjimo pobūdis, vertinimo apmokestinimo tikslais pagrindas, atleidimas nuo mokesčiu, apskundimo galimybės, lengvatos. 